\section{Resposta da autora}

Não há quem questione os benefícios dos exercícios físicos. A ginástica formal, em academia, tem muito a oferecer aos seus adeptos. No entanto, como mencionado pelo leitor, observamos que, na prática, no manejo da obesidade infantil, sua simples prescrição acaba não sendo adotada - e, principalmente, mantida em longo prazo - por uma significativa parcela das crianças obesas ${ }^{1}$.

Como apresentado no artigo, são vários os fatores que podem pesar para a baixa adesão a exercícios físicos sistemáticos em academia. Dentre eles está a dificuldade dos pais e/ou responsáveis de levarem as crianças aos centros de esporte, tanto pelo custo quanto pelo deslocamento e disponibilidade de tempo, que deve obedecer a intervalos freqüentes. No entanto, de maneira alguma desestimulamos a prática da ginástica; muito pelo contrário, propomos a atividade física, podendo ela estar estruturada em um centro esportivo ou não ${ }^{2}$.

A questão é não limitar a atividade física à ginástica, pois sabe-se que a obesidade é problema epidêmico, de saúde pública, e que muitos indivíduos, principalmente crianças, dependem de fatores sociais e econômicos que impossibilitam a adesão a tal sistemática de exercícios físicos. Já foi verificado que a atividade física incorporada como estilo de vida, na realização de atividades diárias, potencializa os efeitos da perda de peso, assim como iniciativas que reforçam a redução de comportamentos sedentários ${ }^{3}$.

Portanto, defendemos um cotidiano mais ativo, onde a atividade possa ser efetivamente incorporada como hábito de saúde e estilo de vida. Para tanto, pode-se oferecer alternativas à criança dentro de sua realidade pessoal, de preferência atividades que sejam lúdicas, típicas da infância, como pular corda, jogar balão, brincar no quintal de casa, praça do edifício ou bairro, caminhar na quadra, dentre tantas outras atividades diárias. A ginástica regular, com certeza, continua como uma boa opção, mas não uma regra.

\section{Elza Daniel Mello}

Doutora em Pediatria. Professora, Departamento de Pediatria, Faculdade de Medicina, Universidade Federal do Rio Grande do Sul (FAMED-UFRGS).

\section{Vivian Luft}

Acadêmica do Curso de Nutrição, FAMED-UFRGS.

\section{Referências}

1. Epstein LH, Wing RR, Koeske R, Valoski A. A comparison of lifestyle exercise, aerobic exercise and calisthenics on weight loss in obese children. Behav Ther. 1985;16:345-56.

2. Epstein LH, Paluch RA, Gordy CC, Dorn J. Decreasing sedentary behaviours in treating pediatric obesity. Arch Pediatr Adolesc Med. $2000 ; 154: 220-6$.

3. Summerbell CD, Ashton V, Campbell KJ, Edmunds L, Kelly S, Waters $E$. Interventions for treating obesity in children. Cochrane Database Syst Rev. 2003;(3):CD001872.

\section{Functional psychosis in childhood and adolescence}

\section{Dear Editors,}

We read with great interest the Supplement 2 of the Jornal de Pediatria about Mental Health, especially the paper entitled "Functional Psychosis in Childhood and Adolescence" by Tengan \& Maia. ${ }^{1}$ They discussed in this text an important issue in child psychiatry, the distinction between childhood-onset schizophrenia and autism.

Since the works of Kolvin \& Rutter, ${ }^{2}$ autism was reliably separated from early-onset schizophrenia, becoming one of the best-validated distinctions in child psychiatry, but a striking feature of childhood-onset schizophrenia samples relative to adult-onset schizophrenia is the higher rate of early language, social, and motor developmental abnormalities. Pre-morbid social impairment was the most common feature, present in $50-87 \%$ of childhood-onset schizophrenia cases across five independent research centers. ${ }^{3}$

The full syndromes of schizophrenia and autism seem to be distinct, however it is possible that a subgroup of those with childhood-onset schizophrenia and those with autism share a similar genetic compound. ${ }^{4}$ Yan et al. ${ }^{5}$ reported a balanced translocation between chromosomes 1 and 7 in a boy with childhood-onset schizophrenia. The breakpoints were at the short arm of chromosome 1 (region p22) and at the long arm of chromosome 7 (region q21). This report is very interesting given a previous case of chromosomal rearrangement involving chromosomes 1, 7 and 21 in an autistic boy where the breakpoint at chromosome 1 was also in the region $\mathrm{p} 22 .{ }^{6}$ These findings make the breakpoints of chromosomes 1 and 7 likely sites for molecular genetic studies. These regions may present genes which may be involved in the etiopathology of childhood-onset schizophrenia and autism, thus these two disorders, apparently so distinct, may present a common biological basis in some cases, consisting of phenotypic variants of a very early onset illness. ${ }^{3}$

\section{Quirino Cordeiro}

Postgraduate Program, Department of Psychiatry, School of Medicine, Universidade de São Paulo (USP), São Paulo, SP, Brazil. E-mail: qcordeiro@yahoo.com

\section{Homero Vallada}

Associate professor, Department of Psychiatry, School of Medicine, Universidade de São Paulo (USP), São Paulo, SP, Brazil.

E-mail: hvallada@usp.br

\section{References}

1. Tengan K, Maia AK. Functional psychosis in childhood and adolescence. J Pediatr (Rio J). 2004;80(2 Suppl):S3-10.

2. Rutter M. Childhood schizophrenia reconsidered. J Autism Child Schizophr. 1972;2:315-7. 
3. Sporn AL, Addington AM, Gogtay N, Ordoñez AE, Gornick M, Clasen $\mathrm{L}$, et al. Pervasive developmental disorder and childhoodonset schizophrenia: comorbid disorder or a phenotypic variant of a very early onset illness? Biol Psychiatry. 2004;55:989-94.

4. Thapar A, Scourfield J. Childhood disorders. In: McGuffin P, Owen M, Gottesman II, editors. Psychiatric Genetics and Genomics. 1st ed. New York: Oxford University Press; 2002. p. 147-180.
5. Yan WL, Guan XY, Green ED, Nicolson R, Yap TK, Zhang J, et al. Childhood-onset schizophrenia/autistic disorder and $t(1 ; 7)$ reciprocal translocation: identification of a BAC contig spanning the translocation breakpoint at 7q21. Am J Med Genet. 2000;96:749-53.

6. Lopreiato JO, Wulfsberg EA. A complex chromosome rearrangement in a boy with autism. J Dev Behav Pediatr. 1992;13:281-3. 